\title{
Model GELPITAS (gerak E lagu, picture E picture, talking stick) untuk meningkatkan perkembangan bahasa Inggris anak taman kanak-kanak
}

\author{
Ratna Purwanti *, Suhaimi Suhaimi \\ Universitas Lambung Mangkurat. Jalan Brigjen H. Hasan Basri, Kayu Tangi, Banjarmasin, Indonesia \\ * Corresponding Author. Email: ratnaulm@gmail.com
}

Received: 15 February 2020; Revised: 24 September 2020; Accepted: 27 September 2020

\begin{abstract}
Abstrak: Tujuan Penelitian ini untuk mendeskripsikan motivasi dan aktivitas siswa serta hasil perkembangan bahasa inggris anak dengan menggunakan Gelpitas, karena pentingnya Bahasa Inggris untuk anak usia dini di masa emas agar dapat bersaing di dunia global ketika mereka beranjak dewasa nanti. Penelitian ini menggunakan pendekatan kualitatif dengan jenis penelitian yaitu Penelitian Tindakan Kelas (PTK) dalam empat pertemuan. Hasil penelitian menunjukan bahwa motivasi anak meningkat dan aktivitas anak secara klasikal dengan kategori sangat aktif. Hasil kemampuan anak mencapai ketuntasan klasikal dengan berkembang sangat baik dan telah memenuhi indikator keberhasilan. Dapat disimpulkan bahwa melalui Gelpitas (gerak dan lagu, model picture and picture, model Talking Stick) dapat meningkatkan kemampuan anak dalam perkembangan bahasa (Bahasa Inggris) pada anak Kelompok B Taman Kanak-kanak.
\end{abstract}

Kata Kunci: Model Gelpitas (Gerak dan lagu, Picture and picture, Talking Stick), Perkembangan Bahasa Inggris anak TK

\section{GELPITAS model (gerak \& lagu, picture E picture, talking stick) to improve development English early childhood}

\begin{abstract}
The purpose of this research is to describe student motivation and activities, the results of students' English development using Gelpitas, because of the importance of English for early childhood in the golden age to be able to compete in the global world when they grow up later. This study uses a qualitative approach to the type of research that is Classroom Action Research (CAR) in four meetings. The result shows that children motivation increases and the classical activities of children with a very active category. The results of children's ability to achieve classical completeness by developing very well and have met the indicators of success. It can be concluded that through Gelpitas (motion and song, picture and picture model, Talking Stick model) can improve children's ability in language development (English) in Group B Kindergarten children.
\end{abstract}

Keywords: Gelpitas Model (Movement and song method, Picture and picture model, Talking Stick model), Language development (English) for earlychildhood

How to Cite: Purwanti, R., \& Suhaimi, S. (2020). Model GELPITAS (gerak \& lagu, picture \& picture, talking stick) untuk meningkatkan perkembangan bahasa Inggris anak taman kanak-kanak. JPPM (Jurnal Pendidikan dan Pemberdayaan Masyarakat), 7(2), 124-134. doi:https://doi.org/10.21831/jppm.v7i2.30204

\section{PENDAHULUAN}

Usia dini merupakan masa peka untuk mengembangkan kemampuan kognitif, afektif, psikomotorik, bahasa, sosio-emosional dan spiritual (Wahyudin \& Agustin, 2012). Suyadi dan Ulfah (2013) menyatakan bahwa setiap anak memiliki masa peka yang berbeda, jika masa peka tersebut tidak dipergunakan secara optimal, maka tidak akan ada lagi kesempatan bagi anak 


\section{JPPM (Jurnal Pendidikan dan Pemberdayaan Masyarakat), 7 (2), 2020 - 125}

Ratna Purwanti, Suhaimi Suhaimi

untuk mendapatkan masa peka tersebut kembali, tugas seorang guru adalah mengamati dengan teliti setiap dari aspek perkembangan anak yang berhubungan dengan masa pekanya dan dapat memprediksi timbulnya masa peka tersebut dari minat anak pada saat itu. Sejalan dengan pendapat Mulyasa (2012) proses perkembangan manusia secara utuh telah dimulai sejak janin dalam kandungan ibunya dan memasuki usia emas (golden age) sampai usia enam tahun adalah masa peka bagi anak karena perkembangan kecerdasannya mengalami peningkatan yang sangat signifikan yang tidak boleh terlewatkan hal ini penting karena pada masa ini terjadi pematangan fungsi-fungsi fisik dan psikis yang siap merespons stimulasi yang datang dari lingkungannya.

Dapat disimpulkan bahwa masa anak usia dini adalah masa peka yang sangat penting bagi anak karena ini adalah masa yang tepat untuk mengembangkan segala aspek kemampuan anak usia dini seperti perkembangan bahasa. Oleh karena itu sangatlah penting peran guru dalam mengamati setiap aspek perkembangan anak yang berhubungan dengan masa pekanya. Menurut Susanto (2017) anak usia dini adalah individu yang sedang mengalami proses pertumbuhan dan perkembangan yang sangat pesat. Terutama usia 4-6 tahun, seorang anak memiliki karakteristik dalam yaitu perkembangan Bahasa yang juga semakin baik, anak sudah mampu memahami pembicaraan orang lain dan mampu mengungkapkan pikirannya dalam batas-batas tertentu.

Pada perkembangan bahasa anak, ketika anak-anak masih relatif kecil (bayi), bahasa yang digunakan adalah bahasa isyarat yang ditunjukkan melalui ekspresi wajahnya dan semakin besar usia anak maka akan terlihat pula bahasa dari lisannya, bahasa sangat penting sehingga harus ditanamkan sejak usia dini agar seorang anak memiliki kemampuan berbahasa yang baik ketika dewasa nanti (Fadlillah, 2012). Aspek bahasa berkembang dimulai dengan peniruan bunyi, selanjutnya berhubungan erat dengan perkembangan kemampuan intelektual dan sosial (Susanto, 2011). Anak melewati masa-masa tertentu dalam perkembangannya dan lebih mudah untuk belajar, periode paling sensitif terhadap bahasa dalam kehidupan seseorang dari mulai lahir sampai enam tahun (Sujiyono, 2012). Menurut Suyanto (2008) hingga usia dua tahun perilaku anak-anak masih bersifat motorik, anak belum benar-benar memahami hal-hal yang terjadi dan belum berpikir secara konseptual sehingga belajar bahasa terjadi karena adanya interaksi. Ada beberapa teori psikologi perkembangan yang relevan dan terkait dengan pengenalan bahasa, termasuk bahasa asing. Salah satunya yaitu tenatng teori perkembangan bahasa pertama atau bahasa ibu yang diperoleh seorang anak yaitu pada usia dua tahun dimana berfungsi untuk membuat suatu perubahan di dalam aspek perkembangan kognitif. Karena bahasa merupakan alat bagi anak untuk membuka peluang guna melakukan sesuatu dan menata informasi melalui penggunaan kata-kata. Oleh karena itu, sering ditemukannya anak yang berbicara sendiri ketika bermain.

Berdasarkan uraian di atas, perkembangan bahasa sebagai salah satu dari kemampuan dasar yang harus dimiliki oleh setiap anak, sebab bahasa diperlukan dalam berkomunikasi dengan lingkungan di dalam suatu masyarakat. Belajar bahasa yang sangat krusial terjadi pada anak sebelum enam tahun melalui interaksi yang dilakukan oleh anak baik dengan lingkungan keluarga, lingkungan tetangga maupun di sekolah bersama guru dan teman. Bahasa mempunyai peran yang sangat penting bagi kehidupan manusia yaitu sebagai alat komunikasi sosial. Namun terkadang komunikasi menjadi terbatas karena adanya perbedaan bahasa antara negara yang satu dengan yang lain, sehingga membutuhkan bahasa pemersatu atau bahasa internasional yang dimengerti oleh setiap negara yaitu Bahasa Inggris. Bahasa Inggris merupakan bahasa internasional yang juga merupakan bahasa yang diajarkan secara luas dan dikuasai banyak negara maju di dunia. Menurut Suyanto (2008) pentingnya peranan Bahasa Inggris dan sumber daya manusia (guru) yang memiliki keandalan berkomunikasi dalam Bahasa Inggris, yang di Indonesia merupakan Bahasa Asing.

Gusrayani (2014) menyatakan bahwa Bahasa Inggris merupakan bahasa internasional, di Indonesia banyak kalangan masyarakat menengah ke atas membahasainggriskan anak-anak sejak dini, bahkan dimulai sejak bayi. Sejalan dengan pendapat. Gusrayani (2014, p. 8) menyatakan pada saat memperkenalkan Bahasa Inggris pada anak sejak dini, jangan 


\section{JPPM (Jurnal Pendidikan dan Pemberdayaan Masyarakat), 7 (2), 2020 - 126}

Ratna Purwanti, Suhaimi Suhaimi

terjemahkan artinya, cukup tunjuk makna yang dimaksud atau dengan sesuatu yang konkret. Kemudian Aslamiah et al. (2020) menyatakan bahwa Bahasa Inggris adalah bahasa internasional yang sangat tepat diajarkan sejak dini.

Dapat disimpulkan bahwa Bahasa Inggris merupakan bahasa yang penting untuk dipelajari. Sebuah negara yang menguasai Bahasa Inggris, dapat dikatakan telah memasuki era globalisasi dan dapat menjalin berbagai macam hubungan internasional dengan negara lain. Hal inilah yang menjadi alasan semakin banyak orang yang berusaha mempelajari Bahasa Inggris dengan baik agar mampu bersaing secara global serta mengenalkan Bahasa Inggris sejak dini kepada anak. Anak memiliki masa-masa tertentu dalam perkembangan, dengan bertambahnya usia, setiap anak mengalami perkembangan bahasa dan konsep dengan cepat apalagi jika didukung dengan pengenalan aspek (bahasa inggris) sejak usia dini agar bermanfaat untuk mereka disaat beranjak dewasa dalam bersaing dengan dunia. Usia dini adalah masa peka atau periode sensitif anak untuk mengenalkan aspek bahasa (Bahasa Inggris). Oleh karena itu, dalam mengenalkan Bahasa Inggris kepada anak usia dini harus dilakukan dengan kegiatan yang bersifat konkret, agar anak mampu memahami apa yang dimaksud. Adapun contoh dari materi yang dapat dikenalkan kepada anak usia dini yaitu salah satunya yang berhubungan dengan kemampuan anak seperti materi tentang warna dan angka. Gusrayani (2014) menyatakan bahwa para guru harus lebih kreatif dan inovatif dalam pengembangan aspek bahasa (Bahasa Inggris) dalam mengenalkan Bahasa Inggris anak usia dini di kelas sesuai dengan kebutuhan dan karakteristik anak, guru harus dapat mengelola kegiatan yang dilaksanakan di kelas dengan baik dan terarah, hal yang harus diingat adalah anak masih berpikir konkret, harus memicu guru untuk berusaha mengkonkretkan bahasa yang memang sifatnya abstrak. Dalam pengenalan aspek Bahasa (Bahasa Inggris) pada anak harus didukung oleh sumber daya manusia (guru) yang berkualitas, dengan kata lain peningkatan kualitas sumber daya manusia dapat berdampak positif bagi proses pengenalan Bahasa Inggris pada anak. Menurut Susanto (2017) kemampuan guru dalam menciptakan dan merancang kegiatan yang menarik, serta kondusif bagi anak, untuk menciptakan kegiatan yang demikian, guru perlu memahami karakteristik dari anak yang akan dihadapinya.

Guru harus kreatif dan inovatif untuk merancang kegiatan agar anak dapat tertarik. Akan tetapi, pada kenyataannya di lapangan peneliti menemukan bahwa pengenalan Bahasa Inggris pada anak belum maksimal, kebanyakan anak merasa sulit dengan Bahasa Inggris hal ini dikarenakan kegiatan yang dilaksanakan masih abstrak dan tidak menarik. Masalah dalam penelitian ini adalah tentang permasalahan yang terjadi yaitu kurang tertariknya anak dalam mengenal Bahasa Inggris sehingga membuat rendahnya kemampuan anak dalam mengenal aspek bahasa (Bahasa Inggris). Permasalahan ini juga disebabkan karena anak masih bersifat malu-malu dalam menjawab pertanyaan dan bersuara pelan dalam menjawab pertanyaan dari guru, bersikap pasif dalam menjawab pertanyaan dari guru dikegiatan pengenalan aspek bahasa (Bahasa Inggris) secara lisan, bahkan ada beberapa anak yang asyik dengan kegiatannya sendiri hal ini terjadi karena anak merasa jenuh di kelas. Kejenuhan anak ini terjadi karena kegiatan yang dilakukan masih bersifat abstrak dan tidak menarik. Guru yang kurang kreatif dalam mengenalkan Bahasa Inggris pada anak membuat kebanyakan anak merasa sulit dengan Bahasa Inggris karena kurang maksimalnya pemahaman guru tentang model dan metode ataupun media yang seharusnya digunakan agar pengenalan Bahasa Inggris pada anak tercapai. Kejenuhan anak ini juga terjadi karena tidak adanya media yang diberikan guru misalnya melalui gambar yang dapat membuat kegiatan menjadi lebih konkret. Guru tidak menciptakan suasana yang menyenangkan misalnya melalui benyanyi. Selain itu pula tidak adanya kombinasi model pembelajaran dan metode yang diberikan oleh guru akibatnya anak kurang terlibat di dalam kegiatan. Sehingga dengan (media) gambar dan lagu dapat membuat kegiatan menjadi lebih konkret dan membuat anak menjadi tertarik ketika kegiatan berlangsung. Adapun rencana pemecahan masalah untuk memperkenalkan Bahasa Inggris pada anak dengan menggunakan Gelpitas yaitu metode gerak dan lagu, model Picture and Picture, model Talking Stick pada anak Kelompok B di Taman kanak-kanak langkah-langkah yang disesuaikan dengan anak usia dini, 
yaitu (1) guru menyiapkan tema materi pelajaran (GL), (2) Guru menyampaikan kompetensi yang ingin dicapai (GL), (3) guru membentuk kelompok secara heterogen dan memberikan pertanyaan kepada kelompok tentang gambar yang ditunjukkan (PP), (4) Guru memberikan tugas kepada kelompok (mengurutkan gambar) (PP), (5) guru mulai menanamkan konsep melalui pemberian contoh dengan menyanyikan lagu (GL), (6) guru mengajak anak duduk membentuk lingkaran besar kemudian menjalankan tongkat yang diiringi dengan lagu, pada saat lagu berakhir diberikan pertanyaan (dari gambar yang ditunjukkan), demikian seterusnya sampai sebagian besar anak mendapat bagian untuk menjawab setiap pertanyaan dari guru (TS, PP dan GL) dan (7) guru dan anak membuat kesimpulan/rangkuman bersama (TS).

Rachmi, Yusrafiddin, Purnomo, Sopandi, Agus, Djatmiko, (2008) menyatakan bahwa dengan gerak dan lagu terbukti telah menjadi sebuah alat yang ideal bagi anak-anak usia dini untuk belajar dengan cara yang menyenangkan, dan sebagai alat peraga yang paling baik untuk mengajarkan bahasa kepada anak usia dini.

Model Picture and Picture adalah model pembelajaran yang kooperatif atau mengutamakan adanya kelompok-kelompok dengan menggunakan media gambar yang dipasangkan atau diurutkan menjadi urutan logis, yang mengandalkan gambar sebagai media konkret dalam proses pengembangan. Gambar ini menjadi faktor utama tercapainya indikator perkembangan. Gambar sangat penting digunakan untuk memperjelas pengertian, melalui gambar anak mengetahui hal-hal yang belum pernah dilihatnya (Kurniasih \& Sani, 2016). Model pembelajaran lain yang dapat diterapkan yaitu model Talking Stick (tongkat berbicara). Menurut Shoimin (2014) Talking Stick (tongkat berbicara) merupakan salah satu model pembelajaran yang dilakukan dengan bantuan tongkat, siapa yang memegang tongkat wajib menjawab pertanyaan dari guru. Hasil penelitian Saleh dan Sugito (2015) salah satu alternatif pemecahan masalah di kelas ayitu melalui metode pembelajaran. Oktaviana dan Wuryandani (2019) media pembelajaran sangat penting untuk meningkatkan ketertarikan anak.

Dapat disimpulkan melalui penggunaan Gelpitas dapat menciptakan suasana kegiatan menjadi lebih konkret dan menarik minat anak karena dengan sesuatu yang baru dan tidak pernah anak lihat dan lakukan sebelumnya membuat mereka penasaran dengan kegiatan yang akan dilakukan, melalui media gambar yang diberikan oleh guru maka kegiatan yang dilakukan menjadi lebih konkret, anak menjadi lebih termotivasi dengan melihat gambar tersebut karena anak menyukai hal yang unik, serta dapat menghilangkan kebosanan anak-anak melalui bernyanyi dengan gerakan sehingga dapat membuat anak selalu senang dan juga semakin menyukai Bahasa Inggris.

\section{METODE}

Penelitian ini menggunakan pendekatan kualitatif dengan jenis penelitian yaitu Penelitian Tindakan Kelas (PTK) dalam empat pertemuan. Di setiap pertemuan terdiri dari perencanaan, pelaksanaan tindakan, observasi dan refleksi. Pengumpulan data dilakukan dengan cara observasi aktivitas anak dan hasil kemampuan anak dalam perkembangan Bahasa Inggris. Subjek penelitian adalah anak kelompok B di Taman kanak-kanak yang berjumlah 10 orang. Prosedur pengumpulan data melalui observasi aktivitas anak di kelas selama pembelajaran bahasa (bahasa inggris) serta dokumentasi dari hasil kemampuan perkembangan bahasa (bahasa Inggris). Analisis aktifitas anak dilakukan dengan cara mengamati aktifitas anak selama proses kegiatan berlangsung dengan penilaian indikator seperti anak memperhatikan gambar yang ditunjukkan guru, anak menjawab pertanyaan tentang gambar yang ditunjukkan, anak menyelesaikan tugas (menyusun gambar secara urut) dalam kerjasama kelompok, anak menyanyi disertai dengan gerakan serta anak menyimpulkan. Sehingga Indikator keberhasilan dalam penelitian ini dinyatakan berhasil apabila indikator aktivitas anak dalam kegiatan mengenal aspek bahasa (Bahasa Inggris) dikatakan berhasil jika masing-masing anak mendapatkan kriteria minimal aktif atau mencapai skor minimal $\geq 17$ dengan persentase keseluruhan minimal mencapai $\geq 76 \%$. Kemudian hasil kemampuan anak dalam perkembangan 


\section{JPPM (Jurnal Pendidikan dan Pemberdayaan Masyarakat), 7 (2), 2020 - 128}

Ratna Purwanti, Suhaimi Suhaimi

bahasa (Bahasa Inggris) dikatakan berhasil apabila anak minimal mendapatkategori Berkembang sesuai harapan. Kemudian keberhasilan secara klasikal mencapai $\geq 76 \%$ tergolong Berkembang Sangat Baik (BSB).

\section{HASIL DAN PEMBAHASAN}

\section{Hasil}

Berdasarkan pengamatan yang dilakukan peneliti pada pertemuan 1, 2, 3 dan 4 terhadap aktivitas anak dalam kemampuan perkembangan bahasa (Bahasa Inggris) melalui penggunaan gelpitas metode gerak dan lagu, model picture and picture, model Talking Stick. dapat dilihat pada Tabel 1 .

Tabel 1. Hasil Observasi Anak secara individual dan klasikal

\begin{tabular}{|c|c|c|c|c|c|c|c|c|c|}
\hline \multirow{2}{*}{ No. } & \multirow{2}{*}{ Kategori } & \multicolumn{2}{|c|}{ Pertemuan 1} & \multicolumn{2}{|c|}{ Pertemuan 2} & \multicolumn{2}{|c|}{ Pertemuan 3} & \multicolumn{2}{|c|}{ Pertemuan 4} \\
\hline & & $\%$ & $\mathrm{SA}+\mathrm{A}$ & $\%$ & $\mathrm{SA}+\mathrm{A}$ & $\%$ & $\mathrm{SA}+\mathrm{A}$ & $\%$ & $\mathrm{SA}+\mathrm{A}$ \\
\hline 1. & Sangat Aktif (SA) & $20 \%$ & & $20 \%$ & & $40 \%$ & & $60 \%$ & \\
\hline 2. & Aktif (A) & $30 \%$ & & $40 \%$ & & $30 \%$ & & $40 \%$ & \\
\hline 3. & Cukup Aktif (CA) & $30 \%$ & $50 \%$ & $20 \%$ & $60 \%$ & $20 \%$ & $70 \%$ & $\mathrm{o} \%$ & $100 \%$ \\
\hline 4. & Kurang Aktif (KA) & $20 \%$ & & $20 \%$ & & $10 \%$ & & o\% & \\
\hline \multicolumn{2}{|c|}{ Jumlah } & $100 \%$ & & $100 \%$ & & $100 \%$ & & $100 \%$ & \\
\hline
\end{tabular}

Dari Tabel 1 dapat disimpulkan bahwa aktivitas anak dalam perkembangan bahasa (Bahasa Inggris) melalui kombinasi Gelpitas pada kelompok B di Taman kanak-kanak sudah terlaksana dengan baik dan pencapaian aktivitas anak termasuk dalam kategori aktif dan sangat aktif secara individual mencapai 5 orang anak, cukup aktif 3 orang anak, dan kurang aktif ada 2 orang anak pada pertemuan pertama, dan secara klasikal pada pertemuan kesatu belum memenuhi indikator keberhasilan dengan persentase keseluruhan (jumlah anak aktif dan sangat aktif) yaitu $50 \%$ atau dengan kategori cukup aktif.

Selanjutnya mengalami peningkatan pada pertemuan kedua yaitu 6 orang anak mendapatkan kategori aktif dan sangat aktif, cukup aktif 2 orang anak, dan kurang aktif ada 2 orang anak dan secara klasikal mengalami peningkatan yaitu indikator keberhasilan dengan persentase keseluruhan (jumlah anak aktif dan sangat aktif) yaitu $60 \%$ atau dengan kategori aktif. Pada pertemuan selanjutnya yaitu pertemuan ketiga juga mengalami peningkatan kembali dengan kategori aktif dan sangat aktif yaitu 7 orang anak, cukup aktif 2 orang anak, dan kurang aktif ada 1 orang anak dan secara klasikal mengalami peningkatan pada pertemuan ketiga mencapai indikator keberhasilan dengan persentase keseluruhan (jumlah anak aktif dan sangat aktif) yaitu 70\% atau dengan kategori aktif. Kemudian pertemuan keempat meningkat menjadi 10 orang anak dan mendapat kategori aktif dan sangat aktif serta secara klasikal mencapai indikator keberhasilan dengan persentase keseluruhan (jumlah anak aktif dan sangat aktif) yaitu ${ }_{100} \%$ atau dengan kategori sangat aktif yang dapat dilihat pada Tabel 1.

Kemudian hasil kemampuan anak dalam dalam perkembangan bahasa (Bahasa Inggris) melalui kombinasi Gelpitas (Metode Gerak dan lagu, model pembelajaran Picture and picture, Model Talking Stick) pada anak kelompok B dapat dikatakan berkembang dan terlaksana dengan baik yang dapat dilihat pada setiap pertemuan.

Dapat dilihat pada pertemuan pertama hasil kemampuan anak dalam mengenal aspek bahasa (Bahasa Inggris) yaitu secara individual dan klasikal belum mencapai indikator perkembangan dengan persentase $50 \%$ yaitu 2 anak yang belum berkembang (20\%), 3 orang anak yang mulai berkembang (30\%) dan 5 orang anak berkembang sesuai harapan $(50 \%)$. Pertemuan kedua belum berhasil yaitu 6 orang anak yang berkembang $(60 \%)$ yaitu 2 anak yang belum berkembang $(20 \%), 2$ orang anak yang mulai berkembang $(20 \%), 4$ orang anak berkembang sesuai harapan (50\%) dan 2 orang anak berkembang sangat baik. Pada pertemuan selanjutnya mulai berhasil yaitu 7 orang anak yang berkembang $(70 \%)$ yaitu 3 orang anak yang mulai berkembang (30\%), 2 orang anak berkembang sesuai harapan $(20 \%)$ dan 5 orang anak 
berkembang sangat baik (50\%). Dan pada pertemuan terakhir dapat dikatakan telah berhasil karena mencapai indikator perkembangan dengan persentase yaitu 10 anak yang berkembang (100\%) atau dengan kategori berkembang sangat baik (BSB) yang dapat dilihat pada tabel di atas.

Dapat disimpulkan melalui penggunaan Gelpitas dapat kegiatan pembelajaran Bahasa Inggris membuat suasana kegiatan menjadi lebih konkret dan menarik sehingga minat anak untuk mengetahui sesuatu yang baru, melalui media gambar yang diberikan oleh guru kegiatan yang dilakukan menjadi lebih konkret, anak menjadi lebih termotivasi dengan melihat gambar tersebut karena anak menyukai hal yang unik, serta dapat menghilangkan kebosanan anak-anak melalui bernyanyi dengan gerakan sehingga dapat membuat anak selalu senang dan juga semakin menyukai Bahasa Inggris.

Gambar 1 adalah hasil temuan penelitian yang dimuat di dalam grafik dari hasil aktivitas anak dan hasil kemampuan perkembangan bahasa (Bahasa Inggris) dalam pertemuan 1, 2, 3 dan 4 .

Aktivitas Anak dan Hasil Perkembangan Bahasa (Bahasa Inggris) di Kelompok B Taman Kanak-Kanak
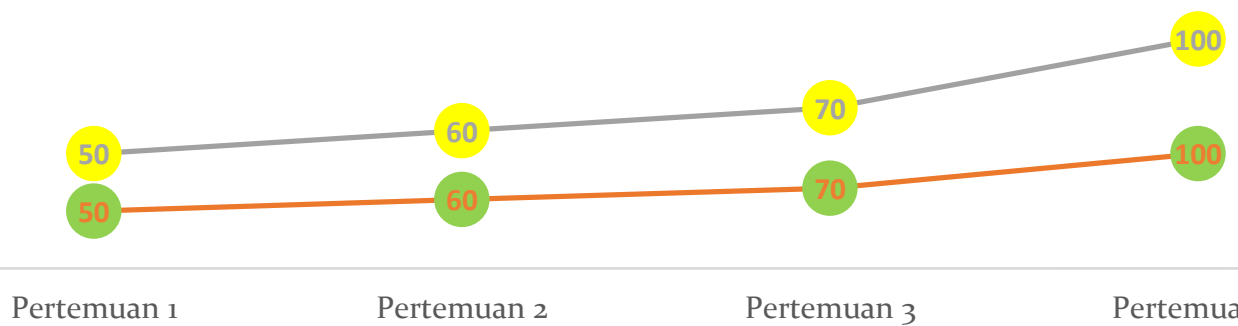

Pertemuan 2

Pertemuan 3

Pertemuan 4

- Aktivitas Anak

—- Hasil kemampuan perkembangan bahasa (Bahasa Inggris)

Gambar 1. Grafik Pertemuan 1, 2, 3 dan 4 (aktivitas anak dan hasil kemampuan perkembangan bahasa (Bahasa Inggris)

Berdasarkan Gambar 1 dapat disimpulkan bahwa sudah ada peningkatan pada setiap pertemuan, sehingga aktivitas anak dan hasil kemampuan anak dalam perkembangan bahasa (Bahasa Inggris) dalam kegiatan pembelajaran di kelas sudah mencapai indikator keberhasilan yaitu $100 \%$ atau berkembang sangat baik. Dilihat dari setiap pertemuan menunjukkan peningkatan yang signifikan melalui kombinasi Gelpitas (Gerak dan lagu, model pembelajaran Picture and picture, Model Talking Stick) pada anak kelompok B.

\section{Pembahasan}

Motivasi

Di dalam kegiatan pembelajaran bahasa inggris di kelas melalui Gelpitas (Gerak dan lagu, model pembelajaran Picture and picture, Model Talking Stick) dapat meningkatkan motivasi anak. Motivasi belajar anak muncul ketika kegiatan yang dilakukan sesuai dengan minat anak dan mendorong rasa ingin tahu anak yang besar, yaitu dengan kegiatan yang menggunakan media gambar, anak menjadi lebih mudah memahami konsep dari apa yang disampaikan. Anak sangat terihat antusias terlihat dari hasil setiap pertemuan anak sangat aktif dan percaya diri dalam mengucapkan apa yang diminta oleh guru di dalam bahasa inggris dengan materi kesukaanku (buah) dan lambang bilangan (jumlah buah yang ada di dalam gambar.

Melalui nyanyian sambil diikuti gerakan, anak tanpa sadar menikmati pembelajaran bahasa inggris yang dilakukan oleh guru. Anak-anak bersemangat sambil bernyanyi dan bergerak karena suasana pembelajaran yang sangat menyenangkan.

Motivasi memegang peranan yang sangat penting, mempengaruhi aktivitas, kesungguhan, dan akhirnya menentukan hasil kemmapuan perkembangan anak. Anak menjadi terbiasa 


\section{JPPM (Jurnal Pendidikan dan Pemberdayaan Masyarakat), 7 (2), 2020 - 130}

Ratna Purwanti, Suhaimi Suhaimi

dengan bahasa Inggris, karena adanya motivasi anak yang tinggi. Bahasa adalah kebiasaan. Jadi bahasa Inggris mudah dipelajari asalkan anak dibiasakan dengan hal tersebut dan dengan motivasi yang tinggi (percaya diri).

\section{Aktivitas Anak}

Dilihat dari tujuan penelitian ini adalah untuk mendeskripsikan aktifitas anak dalam perkembangan bahasa (Bahasa Inggris) melalui penggunaan Gelpitas. Temuan dari penelitian ini menemukan bahwa bahwa hasil aktivitas anak yang dilaksanakan pada pertemuan 1,2,3 dan 4 mencapai $\geq 76 \%$ atau dengan kategori sangat aktif dengan presentase $100 \%$.

Hal ini terjadi karena adanya kombinasi Gelpitas (gerak dan lagu, picture and picture model, talking stick model) yang membuat pembelajaran menjadi konkret untuk anak, sehingga anakpun lebih termotivasi mengikuti kegiatan pembelajaran Bahasa Inggris.

Motivasi belajar anak akan muncul ketika yang dilakukan sesuai dengan minat anak dan rasa ingin tahu anak (Yus, 2011). Sejalan dengan pendapat Sujiyono (2012) menyatakan bahwa seorang anak dapat belajar dengan sebaik-baiknya apabila kebutuhan dipenuhi dan mereka merasa aman dan nyaman secara psikologis, Oleh karena itu mengenal anak dengan dekat agar membuat mereka merasa aman dan nyaman adalah penting.

Guru yang kreatif dalam mengenalkan Bahasa Inggris pada anak membuat kebanyakan anak tidak merasa sulit dengan Bahasa Inggris karena maksimalnya pemahaman guru tentang model dan metode ataupun media yang seharusnya digunakan agar pengenalan Bahasa Inggris pada anak tercapai. Dengan gelpitas (media) gambar dan lagu dapat membuat kegiatan menjadi lebih konkret dan membuat anak menjadi tertarik ketika kegiatann berlangsung. Penggunaan kombinasi Gelpitas (Gerak dan lagu, model pembelajaran Picture and picture, Model Talking Stick) adalah hal yang tepat untuk anak, karena dengan (media) gambar dan lagu dapat membuat kegiatan menjadi lebih konkret dan membuat anak menjadi tertarik ketika kegiatan berlangsung. Menurut Seeteldt (2008) menyatakan bahwa konsep pengenalan Bahasa Inggris pada anak dalam berbahasa yaitu dapat diterapkan pada materi (warna, angka, bentuk, waktu, perasaan, keluarga) sehingga dapat membuat kegiatan yang menyenangkan.

Teori ini di dukung dari hasil penelitian Shen (2009) menemukan bahwa lagu, musik dan lirik memiliki banyak manfaat bagi anak dalam mengenal Bahasa Inggris, lagu menciptakan suasana menyenangkan bagi anak atau jofull learning.

Model Picture and picture adalah model pembelajaran yang kooperatif atau mengutamakan adanya kelompok-kelompok dengan menggunakan media gambar yang dipasangkan atau diurutkan menjadi urutan logis. Kelebihan dari model ini yaitu gambar menjadi faktor utama tercapainya indikator perkembangan, karena gambar sangat penting digunakan untuk memperjelas pengertian, melalui gambar anak mengetahui hal-hal yang belum pernah dilihatnya (Kurniasih \& Sani, 2016). Model pembelajaran Talking Stick melatih anak berani untuk berbicara, sehingga kelas lebih terlihat hidup dan tidak menoton serta anak tidak menjadi kaku ketika kegiatan dilaksanakan (Kurniasih \& Sani, 2016).

Berdasarkan teori yang mendukung di atas peningkatan ini terjadi karena ketepatan guru dalam melakukan upaya perbaikan pada setiap pertemuan di dalam kegiatan pengenalan aspek bahasa (Bahasa Inggris) dengan menggunakan kombinasi Gelpitas (Gerak dan lagu, model pembelajaran Picture and picture, Model Talking Stick) yaitu dengan memotivasi anak untuk tidak malu dalam menjawab pertanyaan dari guru, memotivasi anak untuk percaya diri dalam menjawab karena adanya motivasi yang penuh perhatian dan kasih sayang dari guru lah membuat mereka tidak ragu dalam melakukan sesuatu. Jika dilihat dari karakteristik anak usia dini unik, aktif dan energik yaitu anak senang dan gembira melakukan kegiatan misalnya saja seperti bernyanyi dengan gerakan. Kegiatan seperti akan menciptakan suasana kelas yang menyenangkan. Karakteristik anak yang lainnya yaitu rasa ingin tahu yang kuat dan antusias terhadap banyak hal, eksploratif dan berjiwa petualang serta daya perhatian yang pendek jadi melalui media gambar maka kegiatan akan menjadi lebih konkret dan menarik, anak akan tertarik untuk bertanya lebih jauh tentang gambar yang ditunjukkan oleh guru, anak menjadi 
lebih fokus di dalam kegiatan mengenal aspek bahasa (Bahasa Inggris) dengan adanya gambar. Karena anak memiliki karakteristik bergairah untuk belajar dan banyak belajar dari pengalaman yaitu melalui bernyanyi dengan gerakan, anak dapat bebas mengungkapkan semua ekspresinya sehingga anak bergairah dan lebih termotivasi di dalam kegiatan pembelajaran Bahasa Inggris. Anak semakin menunjukkan minat terhadap teman lain, dari kegiatan kerjasama (mengurutkan gambar) maka anak berhubungan dengan teman-teman lainnya sehingga anak mulai menunjukkan untuk bekerja sama dengan orang lain.

\section{Hasil Kemampuan Perkembangan Bahasa (Bahasa Inggris)}

Temuan dari penelitian ini selanjutnya menemukan bahwa hasil kemampuan Anak dalam perkembangan bahasa (Bahasa Inggris) pada anak selalu mengalami peningkatan dari pertemuan ke 1, 2, 3 dan 4 yaitu secara klasikal mencapai $\geq 76 \%$ pada kategori berkembang sangat baik (BSB) dengan presentase $100 \%$. Karena aktifitas anak yang dilakukan secara konkret sehingga dapat meningkatkan hasil kemampuan perkembangan bahasa anak (Bahasa Inggris). Yang sesuai dengan Dirjen PAUD (2015) tentang tingkat pencapaian perkembangan anak dengan kategori Berkembang Sangat Baik (BSB) yaitu Bila anak sudah dapat melakukannya secara mandiri dan sudah dapat membantu temannya yang belum mencapai kemampuan sesuai dengan indikator yang diharapkan, kategori Berkembang Sesuai Harapan (BSH) yaitu Bila anak sudah dapat melakukannya secara mandiri dan konsisten tanpa harus diingatkan atau dicontohkan oleh guru, kategori Mulai Berkembang (MB) yaitu Bila anak melakukannya masih harus diingatkan atau dibantu oleh guru dan kategori Belum Berkembang (BB) yaitu Bila anak melakukannya harus dengan bimbingan atau dicontohkan oleh guru. Jadi berdasarkan temuan di atas, di dalam penelitian ini dengan penggunaan Gelpitas (Gerak dan lagu, model pembelajaran Picture and picture, Model Talking Stick) dapat me ningkatkan perkembangan bahasa anak (Bahasa Inggris) khususnya aktifitas anak di dalam kegiatan pembelajaran di kelas sehingga membuat hasil perkembangan bahasa (Bahasa Inggris) anak pun ikut meningkat atau pada kategori berkembang sangat baik. Hal ini terlihat dari hasil temuan dari 10 orang anak mendapat skor tertinggi karena mereka dapat melakukannya secara mandiri dan sudah dapat membantu temannya yang belum mencapai kemampuan sesuai dengan indikator yang diharapkan. Oleh karena itu dengan penggunaan kombinasi metode dan model pembelajaran yang tepat dan kreatif dari guru seperti Gelpitas, hasil kemampuan perkembangan bahasa (Bahasa Inggris) anak dapat meningkat, karena dengan pembelajaran konkret anak menjadi tertarik sehingga dengan (media) gambar dan lagu yang disertai dengan gerakan dapat membuat kegiatan menjadi lebih konkret (tidak bersifat abstrak) dan membuat anak menjadi lebih tertarik ketika kegiatan berlangsung dan menciptakan suasana belajar yang menyenangkan atau joyfull learning.

Hasil penelitian ini sejalan dengan pendapat Sujiono (2012) yang menyatakan bahwa anak usia dini belajar melalui active learning, metode yang digunakan adalah memberi pertanyaan kepada anak dan membiarkan berpikir/bertanya pada diri sendiri, sehingga hasil belajar yang didapat merupakan konstruksi anak tersebut. Karena pada dasarnya anak memiliki kemampuan untuk membangun dan mengkreasi pengetahuan sendiri, sehingga sangat penting bagi anak untuk terlibat langsung dalam proses belajar. Pengalaman belajar anak lebih banyak didapat dengan cara bermain sambil belajar (bernyanyi dengan gerakan), melakukan percobaan dengan objek nyata dan melalui pengalaman konkret ayng dilihat dan dirasakan oleh anak. Anak mempunyai kesempatan untuk mengkreasikan dan memanipulasi objek atau ide yang anak dapatkan dari stimulus dan lingkungan sekitarnya.

Dapat disimpulkan pada dasarnya anak memiliki kemampuan untuk mengkreasikan pengetahuan yang dimilikinya sendiri, sehingga sangatlah penting pelibatan anak secara langsung dalam proses kegiatan mengenal aspek bahasa (Bahasa Inggris). Kegiatan yang dilakukan melalui pengalaman anak dengan cara bermain (bernyanyi dengan gerakan) serta melalui pengalaman konkret (gambar). Ini dikarenakan anak adalah seorang pebelajar yang aktif. Anak akan menyerap semua informasi yang datang padanya baik sengaja diberikan oleh 


\section{JPPM (Jurnal Pendidikan dan Pemberdayaan Masyarakat), 7 (2), 2020 - 132}

Ratna Purwanti, Suhaimi Suhaimi

orang disekitar anak maupun yang tidak sengaja datang ke anak. Sehingga melalui kombinasi Gelpitas (Metode Gerak dan lagu, model pembelajaran Picture and picture, Model Talking Stick) terjadi peningkatan dalam setiap pertemuan baik dari aktivitas anak dan hasil kemampuan anak dalam mengenal aspek bahasa (Bahasa Inggris).

Selain teori yang dijelaskan di atas, penelitian ini juga didukung dari penelitian yang sudah dilakukan oleh beberapa orang terkait melalui kombinasi dan Metode gerak dan lagu, model picture and picture, model talking stick, diantaranya yaitu Zubaidah (2015) menemukan bahwa melalui model picture and picture dan model talking stick dapat meningkatkan aspek perkembangan bahasa anak usia dini. Selanjutnya hasil penelitian (Paquette \& Rieq, 2008; Gulo et al, 2017; Albaladejo et all, 2016; Millington, 2011) menemukan bahwa melalui lagu serta gerak dan lagu dapat meningkatkan kemampuan aspek bahasa (Bahasa Inggris) anak di Pendidikan anak usia dini. Lagu memainkan peran penting dalam perkembangan anak usia dini sebagai bahasa kedua. Anak-anak menikmati nyanyian, dan lagu menciptakan suasana yang menyenangkan dalam mengenal Bahasa Inggris. Lagu dapat diajarkan kepada anak dengan jumlah siswa banyak atau sedikit. Dengan lagu kemampuan anak dalam mengenal Bahasa Inggris dapat berkembang, anak menjadi tertarik, ruang kelas menjadi lingkungan belajar yang positif di mana anak-anak berkembang secara akademis, sosial, dan emosional, berbagi kegembiraan kreativitas dengan satu sama lain semua dasar dasar untuk pertumbuhan dan perkembangan anak usia dini serta melalui lagu kegiatan menjadi lebih konkret.

Menurut Muti'ah (2010, pp. 168-170) gerak merupakan sarana ekspresi dan mengalihkan ketakutan, kesedihan, kemarahan, kenikmatan. Gerak menjadi hal yang sangat kreatif bila dipadukan dengan musik yang diinterpretasikan anak menurut caranya masing-masing. Akan tetapi, sebelum anak mampu melakukan gerak yang ekspresif ini, terlebih dahulu ia harus menguasai variasi-variasi dari gerakan tubuhnya. Karena setiap anak berbeda kemampuanya. Dengan cara ini ia dapat mengenali dirinya dan menyadari bahwa "mood" dan perasaanperasaan tertentu dapat dikeluarkan melalui gerakan-gerakan ekspresif. Musik/lagu dapat memberikan perasaan kepuasan dan perasaan nyaman serta dapat bersifat sebagai terapi, musik/lagu mendorong anak untuk memperoleh kesempatan mengekspresikan dirinya, selain itu untuk memberikan kesempatan kepada anak untuk melepaskan emosi yang tertahan maupun mengeluarkan emosi-emosi yang tidak dapat diterima oleh lingkungan.

Anak-anak usia lima tahun mampu melakukan gerakan secara simbolis, mereka bisa mengungkapkan gagasan, perasaan, atau emosi lewat gerak, mereka bisa menciptakan sebuah tarian, sandiwara lucu, atau suatu permainan untuk mengungkapkan perasaan dan pengalaman. Gerak tidak beraturan anak-anak dan goyangan serta lompatan secara spontan anak-anak yang mengiringi music berkembang menuju gerakan yang mneyrupai tarian yang sangat rumit pada anak-anak usia tiga, empat dan lima tahun. Gerak rupanya bagian dari keberadaan alamiah anak-anak usia tiga, empat, dan lima tahun. Anak usia tiga dan empat tahun berlari dan menghempaskan tubuhnya kesana kemari di ruang kelas dan taman bermain; anak usia lima tahun tampak meloncat-loncat, berjingkrak-jingkrak dan berputar-putar ketimbang berjalan biasa. Mulailah dengan mengikuti gerak alami anak-anak usia tiga, empat, lima tahun. Daripada menyuruh mereka untuk bergerak mengikuti musik, sebaiknya guru mulai dengan membentuk gerakan alamiah anak-anak sendiri (Seeteldt, 2008, pp.300-304).

Jadi dapat disimpulkan bahwa dari penjelasan serta grafik di atas menunjukkan adanya hubungan antara aktivitas dalam melaksanakan kegiatan melalui Gelpitas (Gerak dan lagu, model pembelajaran Picture and picture, Model Talking Stick) pada anak kelompok B Taman kanak-kanak maka aktivitas anak semakin aktif dalam mengikuti kegiatan melalui kombinasi Gelpitas demikian pula dengan hasil kemampuan anak dalam perkembangan bahasa (Bahasa Inggris) juga semakin berkembang. Jadi, semakin jelas bahwa penerapan kombinasi Gelpitas (Gerak dan lagu, model pembelajaran Picture and picture, Model Talking Stick) pada anak kelompok B Taman kanak-kanak dapat mengembangkan hasil kemampuan anak dalam Perkembangan bahasa (Bahasa Inggris). Oleh karena itu, usia dini merupakan masa peka terjadinya kematangan fisik dan psikis yang siap merespon stimulasi yang diberikan oleh 


\section{JPPM (Jurnal Pendidikan dan Pemberdayaan Masyarakat), 7 (2), 2020 - 133}

Ratna Purwanti, Suhaimi Suhaimi

lingkungan, salah satunya yaitu perkembangan bahasa, khususnya dalam pembelajarn Bahasa Inggris kepada anak usia dini di masa emas agar dapat bersaing di dunia global ketika mereka beranjak dewasa.

\section{SIMPULAN}

Berdasarkan hasil pembahasan di atas, dapat disimpulkan bahwa melalui Gelpitas (Gerak dan lagu, model pembelajaran Picture and picture, Model Talking Stick) dapat meningkatkan perkembangan bahasa (Bahasa Inggris) anak kelompok B Taman kanak-kanak yaitu pada kategori sangat aktif atau berkembang sangat baik. Melalui Gelpitas, pembelajaran di kelas menjadi lebih konkret, suasana pembelajaran yang menyenangkan, dan dapat meningkatkan motivasi anak dalam pembelajaran Bahasa Inggris. Disarankan kepada guru sebaiknya menerapkan Gelpitas (Gerak dan lagu, model pembelajaran Picture and picture, Model Talking Stick) agar dapat menciptakan suasana menyenangkan dan konkret yang meningkatkan motivasi belajar anak, sehingga anak mendapatkan pengalaman yang nyata dan dapat meningkatkan perkembangan anak khususnya bahasa (Bahasa Inggris).

\section{DAFTAR PUSTAKA}

Albaladejo, S., Coyle, Y., Larios, J.R. (2018). Songs, stories, and vocabulary acquisition in preschool learners of English as a foreign language. Volume 76, August 2018, Pages 116-128, https://doi.org/10.1016/j.system.2018.05.002.

Aslamiah, A., Purwanti, R., Ngadimun,N., Noorhapizah, N., Suriansyah,A., Amelia, R. (2020). Learning English using "Damprak" game in early childhood education, Banjarmasin South Kalimantan Indonesia. EDULEARN2o Proceedings, pp. 928-935.

Dirjen PAUD, (2015). Penilaian pembelajaran pendidikan anak usia dini. direktorat pembinaan pendidikan anak usia dini. Kemendikbud.

Fadlillah, M. (2012). Desain pembelajaran PAUD, panduan untuk pendidik, mahasiswa, dan pengelola pendidikan anak usia dini. Yogyakarta: Ar-Ruzz Media.

Gulo, N. E., Fadillah, F., \& Yuniar, D. (2012). Peningkatan Pembelajaran Pengenalan Bahasa Inggris Melalui Bernyanyi Pada Anak Usia 5-6 Tahun. Jurnal Pendidikan dan Pembelajaran Khatulistiwa, 4(3).

Gusrayani, D. (2014). Teaching english to young learners:(Sebuah telaah konsep mengajar bahasa inggris kepada anak-anak). UPI Press.

Kurniasih, I., \& Sani, B. (2015). Ragam pengembangan model pembelajaran untuk peningkatan profesionalitas guru. Jakarta: Kata Pena.

Millington, N. T. (2011). Using songs effectively to teach English to young learners. Language Education in Asia, 2(1), 134-141.

Mulyasa, H., E. (2012). Manajemen PAUD. Bandung: PT. Remaja Rosdakarya.

Muthiah, D. (2010). Psikologi bermain anak usia dini. Jakarta: Kencana.

Oktaviana, N., \& Wuryandani, W. (2019). Pengembangan media big book untuk meningkatkan perilaku moral anak usia 5-6 tahun. JPPM (Jurnal Pendidikan dan Pemberdayaan Masyarakat), 6(1), 32-40. doi:https://doi.org/10.21831/jppm.v6i1.23371

Paquette, K. R., \& Rieg, S. A. (20o8). Using music to support the literacy development of young English language learners. Early Childhood Education Journal, 36(3), 227-232. https://doi.org/10.1007/s10643-008-0277-9.

Rachmi, T., Yusrafiddin., Purnomo, E., Sopandi, Agus T., Djatmiko, Tedjo.(2008). Ketrampilan musik \& tari. Jakarta: Universitas Terbuka. 
JPPM (Jurnal Pendidikan dan Pemberdayaan Masyarakat), 7 (2), 2020 - 134

Ratna Purwanti, Suhaimi Suhaimi

Saleh, S., \& Sugito, S. (2015). Implementasi metode bermain peran untuk meningkatkan kecerdasan interpersonal anak usia 5-6 tahun di TK Barunawati. JPPM (Jurnal Pendidikan dan Pemberdayaan Masyarakat), 2(1), 85-93. doi:https://doi.org/10.21831/jppm.v2i1.4845

Seeteldt, C. B. (2008). Pendidikan anak usia dini (menyiapkan anak usia tiga, empat dan lima tahun masuk sekolah). Jakarta: PT Indeks.

Shen, C. (2009). Using English songs: An enjoyable and effective approach to Elt. English language teaching, 2(1), 88-94. https://doi.org/10.5539/elt.v2n1p88.

Shoimin, A. (2014). 68 model pembelajarn inovatif dalam Kurikulum 2013. Yogyakarta: Ar-Ruzz Media.

Sujiyono, Y.N. (2012). Konsep dasar pendidikan anak usia dini. Jakarta: PT. Indeks.

Susanto, A. (2011). Perkembangan anak usia dini. Jakarta: Kencana Prenada. Media Group.

Susanto, A. (2017). Pendidikan anak usia dini (konsep dan teori). Jakarta: PT. Bumi Aksara.

Suyadi, S., \& Ulfah, M. (2013). Konsep dasar PAUD. Bandung: PT Remaja Rosdakarya.

Suyanto, K. K. (2007). English for young learners. Jakarta: Bumi Aksara.

Syafei, A. F. R. (2016). Teaching English to Indonesian young learners. Jakarta: Kencana.

Wahyudin, U., \& Agustin, M. (2012). Penilaian perkembangan anak usia dini. Bandung: PT Refika Aditama.

Yus, A. (2011). Model pendidikan anak usia dini. Jakarta: Kencana.

Zubaidah, E. (2015). Perkembangan bahasa anak usia dini dan teknik pengembangan di sekolah. Jurnal Cakrawala Pendidikan, 3(3). doi:https://doi.org/10.21831/cp.v3i3.760o 